\title{
Kompetensi Pemilik dan Pekerja Usaha Mikro Makanan Ringan tentang Mutu Produk di Cilegon dan Pandeglang, Provinsi Banten
}

\author{
MicroEnterpreneur Competencies of Product Quality \\ of Snacks in Cilegon and Pandeglang, Banten Province
}

\author{
Isniyunisyafna Diah Delima ${ }^{1}$, Siti Amanah ${ }^{2}$, Prabowo Tjitropranoto ${ }^{2}$ \\ ${ }^{1}$ Alumni Universitas Sultan Ageng Tirtayasa, Cilegon Banten \\ ${ }^{2}$ Departemen Sains Komunikasi dan Pengembangan Masyarakat, Fakultas Ekologi manusia, \\ Institut Pertanian Bogor, Bogor
}

\begin{abstract}
Demand for quality snacks has increased following consumers understanding on good food for health. The demand requires ability from snacks producers to control product quality. Thus, the research objectives was to analyze the factors related to micro enterpreneur competencies in assuringquality of gipang and ceprek melinjo. A case study was conducted to an owner of food processing of sweet rice crackers (in Bahasa Indonesia called gipang) having five workers in Cilegon and an owner of bitter nut crackers (in Bahasa Indonesia in ceprek melinjo) in Pandeglang. The owner of ceprek melinjo has 50 employee trained to be the partners for producing ceprek melinjo. Data from the ownres and employees were gathered through in depth interviews, discussion and observation. The data collected were social-economics profile of producers, external support, and skills in ensuring product quality. Indentification to strengths, weaknesses, opportunities, and threats (SWOT) was also done to help formulating strategy for competencies development. The results show that in general, competencies of gipang small producers are high. While competence ceprek melinjo small producers are low.Competencies possessedbythe small producersgipang and ceprek melinjoisonlybased on the capabilitiesacquiredfrom generation to generation, andthere has been noeffortto increase it.Related to this, it takes efforttoimprove the competence ofthe small producers processinggipang and ceprek melinjothusimproving the competenceexpected to improvethe abilityto expand its business. So that productivitycan be increasedeffortsnotonlyin terms of quantitybutin terms of quality. The strategyto strengthen competencies of small producers shouldbe focused on providing relevant training, facilitation in product marketing, and controlling product quality.
\end{abstract}

Keywords: Small producers, competencies, local snacks, product quality assurance

\begin{abstract}
Abstrak
Permintaan akan makanan ringan berkualitas telah meningkat seiring dengan meningkatnya pemahaman konsumen akan makanan sehat. Permintaan konsumen tersebut memerlukan respon produsen makanan ringan untuk mengontrol kualitas produk. Berkaitan dengan hal itu, tujuan penelitian adalah menganalisis faktor-faktor terkait kompetensi kewirausahaan mikro dalam menjamin kualitas gipang dan ceprek melinjo. Sebuah studi kasus dilakukan terhadap satu pemilik pengolahan gipang di Cilegon dengan lima pekerja dan satu pemilik melinjo ceprek di Pandeglang. Pemilik ceprek melinjo memiliki 50 karyawan dilatih menjadi mitra dalam memproduksi ceprek melinjo. Data dari pemilik dan karyawan dikumpulkan melalui wawancara mendalam, diskusi dan observasi. Data tersebut meliputi: profil sosial-ekonomi, dukungan eksternal, dan keterampilan penjaminan kualitas produk. Identifikasi kekuatan, kelemahan, peluang, dan ancaman (SWOT) juga dilakukan guna merumuskan strategi pengembangan kompetensi. Hasil penelitian menunjukkan bahwa secara umum, kompetensi pemilik dan pekerja usaha gipang tinggi; sedangkan kompetensi pemilik dan pekerja usaha ceprek melinjo rendah. Kompetensi pemilik dan pekerja usaha gipang dan ceprek melinjo diperoleh secara turun temurun, dan belum ada upaya untuk meningkatkannya. Peningkatan kompetensi pemilik dan pekerja usaha gipang dan ceprek melinjo diperlukan dalam hal pengembangan usaha. Produktivitas usaha perlu dipertahankan disertai penjaminan kualitas. Strategi meningkatkan kompetensi pemilik dan pekerja usahadapat dilakukan dengan pelatihan penjaminan mutu produk, pendampingan, dan perluasan pemasaran produk.
\end{abstract}

Kata kunci: Usaha kecil, kompetensi, jajanan local, jaminan mutu produk

\section{Pendahuluan}

Kompetensi pemilik dan pekerja usaha mikrotentang pengolahan dan mutu produk senantiasa harus ditingkatkan. Pengolahan makanan ringan terutama gipang dan ceprek melinjo, merupakan usaha kecil dan mikro yang berkembang di berbagai daerah di Indonesia, termasuk di Banten. Daerah Banten dan sekitarnya, memiliki potensi beras ketan dan melinjo yang dapat diolah menjadi gipang daripada dan ceprek melinjo. Produk hasil olahan ini dipasarkan kepada masyarakat setempat dan wisatawan. Kesulitan yang dihadapi oleh pemilik dan pekerja usaha pengolahan pangan pembuatan gipang antara lain, kurangnya

${ }^{1}$ Korespondensi penulis 
modal dan pemasaran dalam menjual gipang kepada konsumen Susilo (2008). Sampai saat ini, pengolahan gipang dan ceprek melinjo di Banten dilakukan secara sederhana di rumah penduduk. Produk gipang sudah dikemas sesuai dengan kebutuhan konsumen namun ceprek melinjo belum dikemas dengan baik. Produk gipang dikemas dengan menggunakan toples plastik dan ceprek melinjo dikemas dengan menggunakan plastik putih transparan.

Spencer dan Spencer (1993) mendefinisikan kompetensi sebagai bentuk motif, sikap, keterampilan, pengetahuan, perilaku atau karakteristik pribadi lain yang penting untuk melaksanakan pekerjaan. Mulyasa (2002) menyebutkan bahwa kompetensi merupakan perpaduan dari pengetahuan, sikap dan nilai, serta keterampilan yang direfleksikan dalam kebiasaan berpikir dan bertindak. Kompetensi menentukan perilaku dan kinerja seseorang dalam situasi dan peran yang beragam. Sampai saat ini, kompetensi pemilik dan pekerja usahamakanan ringan diperoleh secara turun temurun (Irawan, 2010). Konsumen ceprek melinjo dan gipang mengharapkan mutu produk yang serupa dengan makanan ringan produksi perusahaan pangan.Di sisi lain, kompetensi pemilik dan pekerja usaha mikro pengolahan gipang di Cilegon dan ceprek melinjo di Pandeglang dalam hal penjaminan mutu masih terbatas, dikarenakan masih mengejar pada kuantitas kios-kios di daerah Banten dan sekitarnya.

Penelitian Subaedi tahun 2010 terhadap kinerja UKM di Surabaya memfokuskan pada tiga hal pokok: pengetahuan (knowledge) meliputi pengetahuan manajemen bisnis, pengetahuan produk atau jasa, pengetahuan tentang konsumen, promosi dan strategi pemasaran; keterampilan (skills) meliputi keterampilan produksi, berkomunikasi, kerjasama; dan kemampuan (ability) meliputi kemampuan mengelola bisnis, mengambil keputusan, memimpin, mengendalikan, berinovasi, situasi dan perubahan lingkungan bisnis. Menurut Subaedi (2010), faktor-faktor terkait dengan tingkat kompetensi, meliputi umur, motivasi, pengalaman usaha, jumlah pendapatan dan sumber modal. Semakin tinggi seluruh faktor tersebut dalam derajat tertentu dapat mendukung kompetensi.

Rakhmat (2001) menyatakan bahwa pengalaman berkaitan dengan kepemilikan pengetahuan. Pengalaman dan modal usaha dapat digunakan untuk mengembangkan usaha. Peningkatan pengetahuan dan keterampilan juga diperoleh melalui pelatihan.Marzuki (1992) merujuk pendapat Good
(1973) yang menyatakan bahwa pelatihan merupakan suatu proses membantu orang lain memperoleh keterampilan dan pengetahuan. Menurut Nawawi (1997), pelatihan merupakan proses membantu para pekerja menguasai keterampilan khusus atau memperbaiki kesenjangan dalam melaksanakan pekerjaan.

Dalam usaha kecil mikro makanan ringan, pemilik dan pekerja usaha perlu memiliki kompetensi dalam hal mutu produk yang dihasilkan. Agri-Food Business Development Centre (2007) menyebutkan bahwa kualitas produk pangan dipengaruhi oleh faktor luar dan dalam. Faktor luar adalah hal yang dapat dilihat seperti: warna, flavor, penampakan, bentuk atau ukuran. Faktor dalam merupakan hal yang tidak dapat terlihat, misalnya: rasa, kemanisan, pahit, kesan di mulut atau kandungan gizi.

Beberapa aspek diduga memiliki keterkaitan dengan tingkat kompetensi pemilik dan pekerja usaha mikro tersebut. Aspek tersebut meliputi faktor dari dalam diri pemilik dan pekerja usaha: motivasi, pengalaman usaha, jumlah pendapatan dan sumber modal. Kompetensi akan semakin berkembang apabila memperoleh dukungan eksternal. Aspek tersebut meliputi pelatihan, akses dan pemanfaatan informasi, pengawasan mutu produk dan kemitraan. Adapun kompetensi pemilik dan pekerja usaha pengolahan yang perlu dikuasai menurut Nugraha (2012) meliputi: pengetahuan mutu produk, daya saing, keterampilan pengolahan dan sikap dalam penjaminan mutu.

Daya saing merupakan kemampuan menghasilkan produkbarang danjasayangmemenuhi pengujian internasional, dan dalam saat bersamaan juga dapat memelihara tingkat pendapatan yang tinggi dan berkelanjutan, atau kemampuan daerah menghasilkan tingkat pendapatan dan kesempatan kerja yang tinggi dengan tetap terbuka terhadap persaingan eksternal European Commission (1999). Kualitas/mutu produk makanan yang utama terdiri atas rasa, nilai pangan, dan nilai gizi. Inovasi produk olahan lokal termasuk gipang dan ceprek melinjo dapat dilakukan apabila pemilik dan pekerja usaha memiliki kompetensi yang mendukung. Inovasi tersebut dapat berupa diversifikasi produk, rasa, dan kemasan. Terkait dengan hal tersebut, dibutuhkan penelitian mengenai kompetensi pemilik dan pekerja usaha mikro pengolahan pangan gipang dan ceprek melinjo. Tujuan penelitian adalah menganalisis kompetensi yang dimiliki pemilik dan pekerja usaha makanan ringan 
gipang dan ceprek melinjo; dan memberikan masukan mengenai upaya pengembangan kompetensi sehingga produk yang dihasilkan dapat memenuhi kebutuhan konsumen.

\section{Metode Penelitian}

Penelitian ini didisain sebagai studi kasus, dengan kasus satu pemilik dan pekerja usaha“"Gipang Lestari" di Cilegon dan satu usaha Ceprek Melinjo "Rumah Emping Sari Jaya" di Pandeglang. Pemilik dan pekerja usaha gipang mempunyai lima pekerja dan pemilik dan pekerja usaha ceprek melinjo memiliki 50 orang karyawan sekaligus binaan. Pemilik dan pekerja usaha gipang dipilih secara sengaja karena pemilik dan pekerja usaha tersebut memperoleh penghargaan sebagai pemenang gipang se-Kota Cilegon pada tahun 2011 dan merupakan usaha keluarga. Pemilik dan pekerja usaha ceprek melinjo dipilih secara sengaja dari Desa Menes, Kecamatan Labuan di Kabupaten Pandeglang dengan tipe produk ceprek melinjo yang khas.Pemilik dan pekerja usaha ceprek melinjo memiliki outlet berupa kios.

Data dan informasi dari pemilik dan pekerja usaha dikumpulkan mulai Maret sampai dengan Mei 2015. Wawancara, wawancara mendalam, observasi dan diskusi kelompok. Kuesioner untuk menganalisis hubungan kompetensi dengan aspek sosial ekonomi disusun untuk mengetahui profil sosial ekonomipemilik dan pekerja usaha, meliputi: umur, motivasi instrinsik, motivasi ekstrinsik, pengalaman usaha, jumlah pendapatan (Rp) dan sumber modal; dukungan eksternal, dalam penelitian ini meliputi: frekuensi pelatihan, metode pelatihan, tingkat akses informasi, tingkat pemanfaatan informasi, tingkat pengawasan mutu produk dan kemitraan; dan tingkat kompetensi pemilik dan pekerja usaha mikro pengolahan makanan ringangipang dan ceprek melinjo berkaitan dengan aspek-aspek: pengetahuan tentang mutu produk, pengetahuan tentang daya saing produk, keterampilan pengolahan pangan sesuai dengan standar mutu dan sikap pemilik dan pekerja usaha mikro makanan ringan dalam meningkatkan mutu produk. Jawaban atas pertanyaan dalam kuesioner diskor mulai 1 sampai 3 (Skala ordinal). Skor dalam 3 kategori: tinggi, sedang dan rendah.

Identifikasi SWOT dilakukan melalui pengisian panduan pertanyaan yang terdiri atas 4 pertanyaan. Identifikasi SWOT menurut Rangkuti
(2006) digunakan untuk mengkaji keunggulan kedua usaha, kelemahan yang dimiliki, ancaman yang dihadapi, serta peluang pengembangan. Data diolah secara deskriptif kualitatif. Data mengenai tingkat kompetensi penjaminan mutu \& faktor terkait dianalisis menggunakan korelasi Spearman. Hasil uji korelasi Spearman untuk mengetahui derajat hubungan antara faktor-faktor yang berhubungan dengan kompetensi penjaminan mutu gipang dan ceprek melinjo.

\section{Hasil dan Pembahasan}

\section{Profil Sosial Ekonomi Usaha Mikro Gipang dan Ceprek Melinjo}

\section{Gambaran Umum}

\section{Pemilik dan pekerja usaha mikro gipang.}

Usaha mikro gipang merupakan usaha keluarga yang terdiri dari: Ibu MHM (55 tahun) selaku pemilik usaha, dengan dibantu pekerja Bapak SN (60 tahun), EN (23 tahun), TK(29 tahun), RW (31 tahun) dan AT(17 tahun). Sejak tahun 2010, usaha gipang telah dikembangkan oleh Ibu MHM. Usaha ini beralamat: Kp. Weri RT 01/02, Kelurahan Kebonsari, Kecamatan Citangkil, Kota Cilegon. Arti dari pemberian nama produk makanan ringan ini diberikan merek "Gipang Lestari”, nama ini diberikan berdasarkan gabungan nama-nama dari pemilik dan pekerja usaha mikro makanan ringan gipang. Karena usaha ini dilakukan oleh satu keluarga. Jadi nama produk diambil berdasarkan dari gabungan nama-nama pengolahan makanan ringan gipang. Gipang "LESTARI": $\mathrm{LE}=\mathrm{EV}, \mathrm{S}=\mathrm{SN}$ TARI $=\mathrm{AT}$, TK dan RW. Bapak SN merupakan suami dari Ibu MHM, sedangkan yang lainnya merupakan anak-anak dari Ibu MHM dan Bapak SN.

Modal usaha gipang ini berasal dari modal keluarga. Kesulitan pemilik dan pekerja usaha gipang ini memasarkan produk makanan ringan gipang kepada konsumen. Gipang lestari belum disalurkan ke pasar. Belum ada diferensiasi tugas pada pekerja secara khusus. Sumber daya manusia yang ada pada saat ini seluruhnya mengolah bahan baku menjadi gipang. Penjualan gipang dilakukan oleh Ibu MHM dengan cara berjualan dirumah, dan menitipkan kepada orang yang bekerja di PT. Sankyu Anyer untuk dijual di koperasinya. Pemilik usaha gipang (Ibu MHM) mengatakan terkadang ada pula pembeli 
gipang beberapa toples dan selanjutnya dititipkan ketempat makan. Ada juga konsumen yang datang langsung kerumah. Keberadaan lokasi usaha diketahui konsumen dari merek atau label Gipang Lestari yang terdapat pada kemasan atau toples plastik gipang.

\section{Pemilik dan pekerja usaha ceprek melinjo.}

Usaha ceprek melinjo dimiliki olehseorang pemilik usaha dan keluarganya.Usaha ini didukung oleh 50 orang pekerja yang dilatih khusus oleh Pemilik Usaha. Pemilik dan pekerja usaha ceprek melinjo dalam proses pengolahan dengan cara belajar secara langsung ke orang yang memiliki pengalaman yaitu dari karyawan yang sudah memiliki pengalaman kerja lebih lama, dan pemilik usaha. "Rumah Emping Sarijaya" yang mengusahakan ceprek melinjo didirikan pada tahun 1965 di Kabupaten Pandeglang. Sejak 2005 usaha tersebut dikelola oleh generasi kedua, yaitu HD yang merupakan anak dari JS (alm). Rumah Emping Sarijaya memproduksi olahan melinjo menjadi emping dengan 3 rasa yang dapat dinikmati: manis, pedas, dan gurih. Hasil produksi Rumah Emping Sari Jaya dapat ditemukan di pasaran dengan Merek Cula Satu, dikemas dengan wadah plastik atau memakai Toples. Promosi emping ini telah sampai ke Singapura, Malaysia, Perancis, Belanda, Taiwan. Cina, Vietnam, dan India.Pemilik usaha ceprek melinjo (Bapak HD) mengatakan bahwa alasan menekuni usaha ini karena (1) keluarga sudah berpengalaman dalam bidang ini, (2) bahan baku, berupa buah melinjo cukup tersedia di wilayah Banten, (3) ingin mengembangkan usaha keluarga secara mandiri.

Persamaan dan perbedaan yang dimiliki oleh kedua pemilik dan pekerja usaha gipang dan ceprek melinjo. Persamaan usaha ini merupakan usaha yang dilakukan secara turun temurun, makanan ringan khas Banten, pekerja usaha gipang dan ceprek melinjo sebagian besar berstatus sebagai Ibu Rumah Tangga, umur pada pekerja usaha gipang dan ceprek melinjo ini rata-rata 33-36 masih tergolong muda. Dimana rentang umur cukup produktif berada di antara 3135 tahun dengan umur terbanyak adalah $\leq 34$ tahun. Hal ini dapat dilihat bahwa usia ini tergolong usia produktif seseorang dalam bekerja, sehingga mereka lebih memilih bekerja sebagai berwirausaha dengan harapan akan mendapatkan kinerja yang produktif, dan memperoleh keberhasilan dalam hidupnya. Perbedaan pemilik dan pekerja usaha gipang dan ceprek melinjo ini, gipang dengan menggunakan tenaga pekerja dari dalam keluarga sedangkan ceprek melinjo menggunakan tenaga pekerja dari luar akan tetapi yang memiliki pengalaman dalam pengolahan ceprek melinjo. Sumber modal yang digunakan dalam membuka usaha ini, pemilik usaha gipang menggunakan modal sendiri sedangkan ceprek melinjo dengan melakukan pinjaman ke Bank Swasta. Pemilik dan pekerja usaha mikro makanan ringan gipang belum memiliki mitra untuk bekerjasama dalam usaha ini, baik dengan pihak pemerintah, swasta dan LSM. Berbeda halnya dengan pemilik dan pekerja usaha mikro makanan ringan gipang, pemilik dan pekerja usaha mikro makanan ringan ceprek melinjo memiliki mitra untuk bekerjasama dalam usaha makanan ringan ini, baik dengan pihak swasta.

\section{Profil Sosial Ekonomi}

Umur merupakan salah satu faktor yang dapat mempengaruhi perilaku seseorang dalam pembuatan keputusan dan menjaga segala sesuatu, sebagai sesuatu yang baru. Hal tersebut disebabkan oleh umur yang berpengaruh terhadap kecepatan seseorang dalam menerima sesuatu yang baru, selain itu umur juga menggambarkan pengalaman dari diri seseorang sehingga terdapat keragaman perilaku. Seseorang yang semakin tua yaitu dengan umur di atas 50 tahun kemampuan yang di miliki akan berkurang hal ini di sebabkan oleh fungsi kerja otot dan otak yang semakin menurun dan semakin lambat dalam menerima adopsi inovasi, sehingga cenderung dalam melaksanakan kegiatan - kegiatan yang sudah biasa dilakukan. (Padmowihardjo, 1994). Usaha gipang hanya terdiri dari satu orang pemilik usaha yaitu Ibu MHM yang berumur 55 tahun. Pemilik usaha ceprek melinjo terdiri dari satu orang pemilik yang berumur 38 tahun dan karyawan yang berusia antara 13-44 tahun. Pemilik dan pekerja usaha mikro makanan ringan gipang dan ceprek melinjo tidak terlepas dari pekerjaan yang menggunakan tenaga atau kekuatan. Dilihat dari segi umur responden pekerja usaha mikro makanan ringan gipang dan ceprek melinjo, sebagian besar responden berada di umur kategori muda. Hal ini dapat dilihat bahwa usia ini tergolong usia produktif seseorang dalam bekerja, sehingga mereka lebih memilih bekerja sebagai berwirausaha dengan harapan akan mendapatkan kinerja yang produktif, dan memperoleh keberhasilan dalam hidupnya. Umur 
dalam kategori muda ini memungkinkan responden untuk dapat terlibat secara aktif dalam melakukan pengolahan makanan ringan. Hal ini menunjukkan bahwa sebagian pekerja usaha masih dalam kondisi fisik yang mendukung dalam kegiatan pengolahan makanan ringan gipang dan ceprek melinjo. Selain itu, pekerja usaha mikro makanan ringan berumur muda lebih bugar dan tidak memiliki halangan secara fisik yang terkait dengan umur. Walaupun demikian, berdasarkan dari hasil dilapangan bahwa pemilik dan pekerja usaha yang umurnya lebih tua telah memiliki banyak pengalaman dan lebih terampil yang dilakukan secara turun temurun dalam pengolahan makanan ringan khusus pengolahan makanan ringan gipang dan ceprek melinjo.

Pemilik dan pekerja usaha mikro makanan ringan gipang ini motivasi instrinsiknya termasuk dalam kategori tinggi dengan presentase 66,7\%, dimana pada motivasi instrinsik kebanyakan pemilik dan pekerja usaha mikro makanan ringan gipang ini menyatakan bahwa usaha makanan ringan gipang ini merupakan usaha yang menarik. Karena gipang ini merupakan salah satu oleh-oleh makanan ringan yang khas berasal dari Kota Cilegon, Banten. Usaha yang dijalankan ini merupakan usaha yang dilakukan secara turun temurun sejak tahun 2010. Hal ini sejalan dengan penelitian yang dilakukan oleh Inta. P. N. Damanik (2013) bahwa penguatan motivasi dibutuhkan agar usaha pengolahan sagu tidak hanya untuk memperoleh penghasilan, namun juga untuk memelihara budaya yang diwariskan secara turun temurun. Usaha sebagai pemilik dan pekerja usaha mikro makanan ringan gipang ini pun dikarenakan tuntutan kebutuhan ekonomi dan melestarikan usaha turun temurun.Berbeda dengan pemilik dan pekerja usaha mikro makanan ringan gipang, pemilik dan pekerja usaha mikro makanan ringan ceprek melinjo sebagian besar pemilik dan pekerja usaha mikro makanan ringan gipang ini motivasi instrinsiknya termasuk dalam kategori sedang dengan presentase $45,1 \%$, dimana pada motivasi instrinsik sebagian pemilik dan pekerja usaha mikro makanan ringan ceprek melinjo ini merupakan usaha yang menarik. Karena ceprek melinjo ini merupakan salah satu oleh-oleh makanan ringan yang khas berasal dari Kota Pandeglang, Banten. Dan memang hasil pertanian didaerah ini yang paling terkenal adalah emping. Usaha sebagai pemilik dan pekerja usaha mikro makanan ringan ceprek melinjo sebagian besar dikarenakan tuntutan kebutuhan ekonomi.Hal ini menunjukkan bahwa pemilik dan pekerja usaha gipang dan ceprek melinjo memiliki motivasi yang tinggi dan sedang.

Pemilik dan pekerja usaha mikro makanan ringan gipang ini motivasi ekstrinsiknya termasuk dalam kategori tinggi. Hal ini menunjukkan bahwa pengakuan dari masyarakat disekitar lingkungan terhadap usaha yang dijalankan ini merupakan usaha ini meningkatkan semangat usaha. Motivasi ekstrinsik dibutuhkan sebagai dorongan untuk memberikan semangat usaha kepada orang sangat berpengaruh terhadap kemajuan usaha. Penghasilan yang didapat semakin hari semakin bertambah pun ternyata dapat meningkatkan motivasi dalam berusaha. Hasil yang didapatkan dari penjualan makanan ringan gipang ini dapat dikatakan sudah mencukupi kebutuhan hidup keluarga sehari-hari. Dan dengan pemilik dan pekerja usaha mikro makanan ringan gipang bekerja keras dapat mempercepat usaha makanan ringan gipang berkembang.

Tidak terdapat perbedaan dengan pemilik dan pekerja usaha mikro makanan ringan gipang dan pemilik dan pekerja usaha mikro makanan ringan ceprek melinjo sebagian besar pemilik dan pekerja usaha mikro makanan ringan gipang ini motivasi ekstrinsiknya termasuk dalam kategori tinggi. Penghasilan yang didapat semakin hari semakin bertambah pun ternyata dapat meningkatkan motivasi dalam berusaha. Hasil yang didapatkan dari penjualan makanan ringan ceprek melinjo ini dapat dikatakan sudah mencukupi kebutuhan hidup keluarga seharihari. Dan dengan menjadi pemilik dan pekerja usaha mikro makanan ringan ceprek melinjo bekerja keras dapat mempercepat usaha makanan ringan ceprek melinjo berkembang. Hal memang dilakukan oleh pemilik dan pekerja usaha mikro makanan ringan ceprek melinjo dengan cara mempertahankan kualitas pada produk yang dijual. Seperti awal mulanya ceprek melinjo itu hanya tersedia dengan satu rasa, yaitu gurih saja. Namun untuk meningkatkan daya jual agar menarik minat konsumen untuk membeli produk ini, maka rasa ceprek melinjo ini ditambahkan dengan banyak rasa, yaitu manis gula merah dan pedas.Tidak adanya perbedaan motivasi ekstrinsik antara kedua pemilik dan pekerja usaha.Hal ini menunjukkan bahwa pemilik dan pekerja usaha gipang dan ceprek melinjo memiliki motivasi yang tinggi.

Pengalaman usaha merupakan bekal bagi para pemilik dan pekerja usaha mikro makanan ringan 
gipang dan ceprek melinjo untuk melakukan suatu kegiatan usaha pengolahan makanan ringan gipang dan ceprek melinjo, untuk meningkatkan kompetensi mereka harus didukung dengan keahlian dan diikuti oleh pengalaman yang dibidang pengolahan makanan ringan. Pengalaman usaha menjadi pemilik dan pekerja usaha mikro makanan ringan gipang dan ceprek melinjo secara tidak langsung akan berpengaruh pada proses pengambilan keputusan Mardikanto (1993). Pada pemilik dan pekerja usaha mikro makanan ringan gipang ini pengalaman usaha antara 6 tahun yang pada umunya melakukan usaha pengolahan makanan ringan gipang sejak tahun 2010. Berbeda dengan pemilik usaha ceprek melinjo memiliki pengalaman usaha selama 11 tahun. Usahaceprek melinjo ini telah dimulai pada tahun 1965. Akan tetapi sejak 2005 usaha tersebut dikelola oleh generasi kedua, yaitu Bapak HD yang merupakan anak dari JS (alm). Pekerja usaha mikro makanan ringan gipang, sebagian besar pemilik dan pekerja usaha mikro makanan ringan ceprek melinjo memiliki pengalaman usaha antara 20 sampai 35 tahun. Sebagian besar pekerja usaha sudah melakukan Rumah Emping Sari Jaya telah dimulai pada 1965. Hal ini menunjukkan bahwa pemilik dan pekerja sudah cukup berpengalaman dalam pengolahan usaha makanan ringan gipang dan ceprek melinjo.

\section{Accounting terminology}

(1993:39)

mendefinisikan bahwa, pendapatan berasal dari penjualan dan pembelian jasa diukur dengan jumlah yang dibebankan kepada langganan, klaim atas barang jasa yang disampaikan untuk mereka, juga termasuk laba dari investasi dalam kenaikan lainnya pada equity pemilik modal kecuali yang berasal dari penyesuaian modal. Pelaku UKM yang mandiri akan mampu meningkatkan pendapatan Marliati (2008) meraih kemajuan dan menjaga keberlanjutan usaha Utami (2007) untuk mewujudkan kesejahteraan mereka beserta keluarganya. Pemilik usaha mikro makanan ringan gipang ini jumlah pendapatan yang dihasilkan dalam penjualan sebesar Rp. 800.000 perbulan. Jumlah pendapatan ini, tidak selalu sama setiap bulannya. Akan tetapi jumlah pendapatan ini belum dibagi dengan pendapatan para pekerja usaha gipang. Ada bulan-bulan tertentu dimana jumlah pendapatan pemilik dan pekerja usaha mikro makanan ringan gipang ini meningkat, khususnya pada bulan puasa mendekati Hari Raya Idul Fitri (lebaran), biasanya jumlah permintaan gipang ini meningkat dibandingkan dengan bulan-bulan biasa hingga mencapai 500-600 toples perhari. Sedangkan pada bulan-bulan biasa pemilik dan pekerja usaha mikro makanan ringan gipang hanya melakukan pengolahan makanan ringan gipang sebanyak 40-50 toples perhari. Berbeda dengan pemilik dan pekerja usaha mikro makanan ringan gipang, pemilik dan pekerja usaha mikro makanan ringan ceprek melinjo memiliki hasil pendapatan $>$ Rp.5.000.000 dalam sebulan dan meningkat ketika musim liburan. Karena biasanya para wisatawan melewati jalan ini dan mencari oleh-oleh khas Banten. Akan tetapi jumlah pendapatan ini belum dibagi dengan pendapatan para pekerja usaha ceprek melinjo. Hal ini menunjukkan bahwa pendapatan pemilik dan pekerjapengolahan usaha makanan ringan gipang dan ceprek melinjo .

Sumber modal pemilik usaha mikro makanan ringan gipang berasal modal sendiri. Berbeda dengan pemilik usaha ceprek melinjo berasal dari Bank Swasta. Hal tersebut sesuai yang dikemukan oleh Alam S (2006) Modal usaha menjadi satu komponen yang penting di dalam memulai sebuah bisnis. Modal usaha adalah segala sesuatu yang dibutuhkan untuk mendirikan sebuah bisnis atau usaha baru. Modal usaha juga dapat digunakan untuk mengembangkan usaha yang telah dijalankan untuk membuat usaha tersebut menjadi lebih besar skalanya dibandingkan waktu sebelumnya. Selain itu, modal usaha juga bermakna sebagai sebuah keahlian atau kemampuan dari seseorang dimana keahlian ini juga akan memiliki pengaruh atau sebagai alat untuk mengembangkan usaha yang dijalankan. Menurut sumber dana, terbagi dua jenis yaitu: modal sendiri, modal yang didapatkan dari pendanaan yang dari diri sendiri dan modal dari luar, diperoleh dari pihak luar dan bukan dari diri sendiri si pemilik usaha. Hal ini menunjukkan bahwa pemilik usaha gipang dengan menggunakan modal sendiri dan pemilik ceprek melinjo dengan menggunakan modal dari luar (Bank Swasta). Hasil-hasil penelitian tersebut didukung oleh data kuantitatif seperti tercantum pada tabel 1 .

\section{Dukungan Eksternal Pemilik dan Pekerja Usaha Gipang dan Ceprek Melinjo}

Sebagian besar pemilik dan pekerja usaha mikro makanan ringan gipang mengikuti pelatihan \pm 2-3 kali dalam setahun mengenai cara pembuatan gipang yang diadakan di Kelurahan Citangkil. Pelatihan yang diselenggarkan oleh pihak kelurahan 
Tabel 1. Profil Sosial Ekonomi Pemilik dan Pekerja Usaha Gipang "Lestari” di Cilegon dan Ceprek Melinjo "Rumah Emping Sari Jaya" di Pandeglang, 2015

\begin{tabular}{|c|c|c|c|c|}
\hline \multirow{2}{*}{$\begin{array}{c}\text { Profil Pemilik dan Pekerja Usaha } \\
\text { Makanan Ringan }\end{array}$} & \multicolumn{2}{|c|}{ Usaha Gipang } & \multicolumn{2}{|c|}{ Usaha Ceprek Melinjo } \\
\hline & $\begin{array}{c}\text { Pemilik } \\
\text { (1 orang) }\end{array}$ & $\begin{array}{c}\text { Pekerja } \\
\text { (5 orang) }\end{array}$ & $\begin{array}{c}\text { Pemilik } \\
\text { (1 orang) } \\
\end{array}$ & $\begin{array}{c}\text { Pekerja } \\
\text { (50 orang) } \\
\end{array}$ \\
\hline Lama berdiri (tahun) & 6 & - & 50 & - \\
\hline Tipe pemasaran & $\begin{array}{l}\text { Konvensional } \\
\text { (model pembeli } \\
\text { datang ke rumah } \\
\text { pemilik dan } \\
\text { pekerja usaha, } \\
\text { dititip di kios) }\end{array}$ & - & $\begin{array}{l}\text { Sudah } \\
\text { memiliki kios } \\
\text { (pemasaran } \\
\text { luas) }\end{array}$ & - \\
\hline Tipe tenaga kerja & - & $\begin{array}{l}\text { Dari dalam } \\
\text { keluarga }\end{array}$ & - & $\begin{array}{l}\text { Dari luar } \\
\text { keluarga } \\
\text { (kemitraan } \\
\text { melalui } \\
\text { pembinaan) }\end{array}$ \\
\hline Umur (tahun) & 55 & $\begin{array}{l}\text { Rata-rata: } 36 \\
\text { Terendah: } 17 \\
\text { Tertinggi: } 60\end{array}$ & 38 & $\begin{array}{l}\text { Rata-rata: } 33 \\
\text { Terendah: } 13 \\
\text { Tertinggi: } 55\end{array}$ \\
\hline Kemitraan & $\begin{array}{l}\text { Belum menjalin } \\
\text { kemitraan }\end{array}$ & - & Bank swasta & - \\
\hline
\end{tabular}

ini dinilai cukup menguntungkan untuk pemilik dan pekerja usaha mikro makanan ringan gipang khususnya Ibu MHM. Karena dari pelatihan itu dapat menambah wawasan yang sebelumnya tidak pernah dilakukan dalam pengolahan gipang. Berbeda dengan pemilik dan pekerja usaha mikro makanan ringan gipang, seluruh pemilik dan pekerja usaha mikro makanan ringan ceprek melinjo pernah mengikuti pelatihan \pm 1 kali dalam setahun mengenai cara pembuatan ceprek melinjo yang diadakan di kelurahan Cikedal. Pelatihan yang diselenggarkan oleh pihak kelurahan ini dinilai menguntungkan untuk pemilik dan pekerja usaha mikro makanan ringan ceprek melinjo. Karena dari pelatihan itu dapat menambah wawasan yang sebelumnya tidak pernah dilakukan dalam pengolahan ceprek melinjo.

Metode pelatihan yang pernah diikuti oleh pemilik dan pekerja usaha mikro makanan ringan gipang melalui cara demonstrasi dan ceramah. Metode pelatihan dengan cara informal memberi kesempatan interaksi dan umpan balik diantara pelatih dengan pemilik dan pekerja usaha mikro makanan ringan gipang. Dalam pelatihan informal ini pemilik dan pekerja usaha mikro makanan ringan belajar secara informal dari pelatih atau peserta lainnya yang mengikuti pelatihan tersebut. Sedangkan demonstrasi dengan cara peragaan dan penjelasan bagaimana mengerjakan suatu pekerjaan melalui contoh-contoh atau pekerjaan yang didemonstrasikan. Pelatih langsung memperagakan secara langsung bagaimana cara pembuatan gipang. Metode ceramah diberikan kepada peserta yang banyak didalam kelas, dimana pelatih mengajarkan teori-teori sedangkan yang dilatih mencatat dan mempersiapkannya. Jadi pada metode pelatihan ini sebelum pelatih mendemonstrasikan cara pembuatan makanan ringan gipang, diberikan penjelasan terlebih dahulu baru setelah itu langsung melakukan peragaan atau demonstrasi. Pelatihan yang diselenggarkan di Kelurahan Citangkil dinilai cukup menguntungkan untuk pemilik dan pekerja usaha mikro makanan ringan gipang khususnya Ibu MHM, karena dari pelatihan itu dapat menambah wawasan yang sebelumnya tidak pernah dilakukan dalam pengolahan gipang. Berbeda dengan pemilik dan pekerja usaha mikro makanan ringan gipang, pemilik dan pekerja usaha mikro makanan ringan ceprek melinjo, maka sebagian besar pemilik dan pekerja usaha mikro makanan ringan ceprek melinjo memperoleh pelatihan secara demonstrasi.

Metode pelatihan dengan cara informal dimana terjadi interaksi dan umpan balik diantara pelatih dengan pemilik dan pekerja usaha mikro makanan ringan ceprek melinjo. Dalam pelatihan 
informal ini pemilik dan pekerja usaha mikro makanan ringan belajar secara informal dari pelatih atau peserta lainnya yang mengikuti pelatihan tersebut. Sedangkan demonstrasi dengan cara peragaan dan penjelasan bagaimana mengerjakan suatu pekerjaan melalui contoh-contoh atau pekerjaan yang didemonstrasikan. Jadi pada metode pelatihan ini pelatih langsung memperagakan secara langsung bagaimana cara pembuatan ceprek melinjo mulai dari memilih jenis melinjo yang akan dipilih untuk pembuatan ceprek melinjo hingga pada mengkemas produk ceprek melinjo. Hal tersebut sesuai yang dikemukan oleh Hickerson dan Middleton (1975) yang mengatakan bahwa pelatihan merupakan proses pembelajaran yang dirancang untuk merubah kinerja dalam melakukan pekerjaannya. Dalam merancang suatu pelatihan agar efektif dalam mencapai tujuannya, ada dua hal utama yang perlu diperhatikan, yaitu: pendekatan atau metode pembelajaran yang digunakan dan rancangan penyajian materi pelatihan. Pelatihan dapat didefinisikan sebagai suatu cara yang digunakan untuk memberikan atau meningkatkan keterampilan yang dibutuhkan untuk melaksanakan pekerjaan sekarang. Pelatihan adalah suatu proses membantu orang lain dalam memperoleh skill dan pengetahuan. Bahwa pelatihan pada dasarnya adalah proses memberikan bantuan bagi para pekerja untuk menguasai keterampilan khusus atau membantu untuk memperbaiki kekurangannya dalam melaksanakan pekerjaan. Fokus kegiatannya adalah untuk meningkatkan kemampuan kerja dalam memenuhi kebutuhan tuntutan cara bekerja yang paling efektif pada masa sekarang.Hasil analisis menunjukkan bahwa frekuensi dan metode pelatihan akan mempengaruhi peningkatkan kompetensi pemilik dan pekerja usaha gipang dan ceprek melinjo dalam melakukan pengolahan makanan ringan.

Pemilik dan pekerja usaha mikro makanan ringan gipang memperoleh dan memanfaatkan informasi tentang pengolahan dan mutu dari sesama anggota keluarga, khususnya dari Ibu pemilik usaha Ibu MHM. Sedangkan pemilik dan pekerja usaha mikro makanan ringan ceprek melinjo memperoleh dan memanfaatkan informasi dengan cara belajar secara langsung atau praktek ke orang yang memiliki pengalaman dalam pengolahan ceprek melinjo, ialah dari pekerja yang sudah memiliki pengalaman kerja lebih lama, dan pemilik usaha yaitu Bapak HD. Hal ini dikarenakan usaha yang dijalankan ini merupakan usaha yang dilakukan secara turun temurun sejak tahun
2005. Hali ini sejalan dengan penelitian yang dilakukan oleh Inta. P. N. Damanik (2013) bahwa penguatan motivasi dibutuhkan agar usaha pengolahan sagu tidak hanya untuk memperoleh penghasilan, namun juga untuk memelihara budaya yang diwariskan secara turun temurun.

Pengawasan mutu produk olahan gipang sangat ketat yang dilakukan oleh pemilik dan pekerja usaha termasuk dalam kategori tinggi. Akan tetapi, kurang adanya pengawasan mutu produk olahan dari pihak lain. Pengawasan terhadap mutu produk ceprek melinjo tidak sebaik pada gipang dan termasuk dalam kategori rendah. Walaupun pengawasan juga dilakukan oleh pemilik dan pekerja usaha tetapi karena banyaknya pekerja ceprek melinjo, maka pengawasan tidak dapat dilakukan dengan intensif. Pengawasan mutu produk makanan ringan ini dilakukan dengan 2 cara, yaitu memperhatikan hal-hal yang terlihat seperti: warna makanan tetapi tidak menggunakan bahan pewarna dari bahan berbahaya, bentuk gipang ini sudah sesuai dengan keinginan konsumen, seperti bentuk gipang yang unik atau khas (belah ketupat) untuk menarik perhatian konsumen. Sedangkan faktor yang tidak dapat terlihat diantaranya: rasa pada makanan ringan yang sesuai dengan selera konsumen. Rasa manis gipang tidak terlalu mencolok sehingga menjadi kegemaran konsumen dan bisa dikonsumsi oleh semua kalangan. Rasa pada makanan ringan ceprek melinjo ini sudah sesuai dengan selera konsumen dan tersedia dalam rasa gurih (asin), manis yang berasak dari gula merah dan pedas, dengan demikian konsumen dapat memilih berdasar selera masing-masing. Menjadi kegemaran konsumen agar bisa dikonsumsi oleh semua kalangan. Hal tersebut didukung oleh pendapat Agri-Food Business Development Centre (2007) yang mengatakan bahwa Mutu pangan adalah merupakan karakteristik mutu pangan yang dapat diterima oleh konsumen, sehingga pangan bermutu merupakan pangan produk yang memiliki karakteristik tertentu sehingga dapat sesuai dengan keinginan pelanggan. Mutu produk pangan dipengaruhi oleh a). Faktor luar yang dapat terlihat dan b). Faktor dalam yang tidak dapat terlihat. Pada pasar global diperlukan standar yang menggambarkan karakteristik mutu pangan dan prosesnya karena adanya sifat saling membutuhkan antara produsen dan konsumen. Mutu pangan dapat dihubungkan dengan beberapa hal, yaitu: kualitas sensori yang meliputi bentuk, rasa, tekstur, dan warna; cara mempertahankan produk; keamanan produk dan 
Tabel 2. Sebaran Tingkat Kompetensi Pemilik dan Pekerja Usaha Gipang dan Ceprek Melinjo

\begin{tabular}{|c|c|c|c|c|c|}
\hline \multirow[t]{2}{*}{ Indikator Tingkat Kompetensi } & \multirow[t]{2}{*}{ Kategori } & \multicolumn{2}{|c|}{ Gipang } & \multicolumn{2}{|c|}{$\begin{array}{l}\text { Ceprek } \\
\text { Melinjo }\end{array}$} \\
\hline & & $\mathbf{n}$ & $\%$ & $\mathbf{n}$ & $\%$ \\
\hline \multirow{3}{*}{ Pengetahuan tentang mutu produk } & Rendah $(<=24)$ & 2 & 33,3 & 36 & 70,6 \\
\hline & Sedang (25-27) & 0 & 0,0 & 7 & 13,7 \\
\hline & Tinggi (28-31) & 4 & 66,7 & 8 & 15,7 \\
\hline \multirow{3}{*}{ Pengetahuan tentang daya saing produk } & Rendah $(<=20)$ & 2 & 33,3 & 23 & 45,1 \\
\hline & Sedang (21-23) & 0 & 0,0 & 16 & 31,4 \\
\hline & Tinggi (24-25) & 4 & 66,7 & 12 & 23,5 \\
\hline \multirow{3}{*}{ Keterampilan dalam pengolahan pangan } & Rendah $(<8)$ & 0 & 0,0 & 20 & 39,2 \\
\hline & Sedang $(9-10)$ & 2 & 33,3 & 31 & 60,8 \\
\hline & Tinggi (11-13) & 4 & 66,7 & 0 & 0,0 \\
\hline \multirow{3}{*}{$\begin{array}{l}\text { Sikap pemilik dan pekerja usaha dalam meningkatkan mutu dan } \\
\text { daya saing }\end{array}$} & Rendah $(<9)$ & 6 & 100,0 & 1 & 2,0 \\
\hline & Sedang (9-10) & 0 & 0,0 & 34 & 66,7 \\
\hline & Tinggi (11) & 0 & 0,0 & 16 & 31,4 \\
\hline \multirow{3}{*}{ Tingkat Kompetensi Keseluruhan } & Rendah & 2 & 33,3 & 39 & 76,5 \\
\hline & Sedang & 0 & 0,0 & 5 & 9,8 \\
\hline & Tinggi & 4 & 66,7 & 7 & 13,7 \\
\hline
\end{tabular}

kemasan produk.

Kemitraan merupakan suatu strategi bisnis yang dilakukan oleh dua pihak atau lebih dalam jangka waktu tertentu untuk meraih keuntungan bersama dengan prinsip saling membutuhkan dan saling menguntungkan. Kemitraan merupakan suatu rangkaian proses yang dimulai dengan mengenal calon mitranya, mengetahui posisi keunggulan dan kelemahan usahanya, memulai membangun strategi, melaksanakan, memonitor, dan mengevaluasi sampai target tercapai.Pemilik dan pekerja usaha mikro makanan ringan gipang belum memiliki mitra untuk bekerjasama dalam usaha makanan ringan ini, baik dengan pihak pemerintah, swasta dan LSM. Akan tetapi menurut pemilik usaha gipang Ibu MHM berdasarkan dari hasil wawancara yang dilakukan menyatakan bahwa pemilik dan pekerja usaha gipang ini mendapatkan dukungan dari masyarakat disekitar lingkungan Kota Cilegon dalam menjalankan usaha ini. Penelitian Subaedi (2010) bahwa keterampilan (skills) meliputi keterampilan produksi, berkomunikasi, kerjasama. Kemitraan merupakan suatu strategi bisnis yang dilakukan oleh dua pihak atau lebih dalam jangka waktu tertentu untuk meraih keuntungan bersama dengan prinsip saling membutuhkan dan saling membesarkan. Dengan demikian, keberhasilan kemitraan usaha tergantung pada adanya kesamaan nilai, norma, sikap, dan perilaku dari pemilik dan pekerja yang menjalankan kemitraan tersebut.Pemilik dan pekerja usaha mikro makanan ringan ceprek melinjo memiliki mitra untuk bekerjasama dengan pihak swasta, ialah dengan bank yang menyediakan modal untuk usaha. Hal ini menunjukkan bahwa kemitraan dibutuhkan dalam suatu usaha untuk meraih keuntungan yang lebih baik. Kemitraan pada pemilik usaha gipang belum ada, sedangkan pemilik usaha ceprek melinjo memiliki mitra dengan Bank Swasta.

\section{Tingkat Kompetensi Pemilik dan Pekerja Usaha Gipang dan Ceprek Melinjo}

Hasil analisis menunjukkan bahwa tingkat kompetensi dalam indikator pengetahuan tentang mutu produktergolong dalam kategori tinggi. Keadaan ini menunjukkan bahwamengetahui mutu produk yang seharusnya dimiliki karena tidak ada informasi tentang hal ini yang diterimanya. Mutu produk didasarkan pada pengetahuan turun temurun, yang dirasakan sudah baik karena ternyata digemari oleh konsumen. Sebaliknya pekerja usaha gipang merasa memiliki pengetahuan tentang mutu produk yang berasal baik dari arahan dan bimbingan pemilik usaha maupun berdasarkan 
saran-saran konsumen. Bahan baku yang digunakan dalam pengolahan gipang ini dipilih berdasarkan bahan yang tersedia dipasaran dan memilih yang khas untuk menghasilkan gipang yang hanya dapat dibeli dari pemilik dan pekerja usaha mikro makanan ringan gipang lestari milik Ibu MHM. Bahan baku yang digunakan untuk pengolahan gipang ini antara lain, yaitu: beras ketan putih, beras ketan hitam, kacang tanah (kacang lokal), gula, asam dan minyak. Mutu pada gipang yang diproduksi ini disesuai dengan bahan yang tersedia dipasaran. Bahan baku yang tidak sulit untuk dicari atau didapatkan dipasaran. Dalam pengolahan gipang ini pun, tidak lupa pemilik dan pekerja usaha memperhatikan komentar, harapan dan juga selera yang diberikan oleh konsumen.Sedangkan tingkat kompetensi pemilik dan pekerja usaha ceprek melinjo dalam indikator pengetahuan tentang mutu produktergolong dalam kategori rendah. Keadaan ini menunjukkan bahwapemilik usaha makanan ringan ceprek melinjo dan pekerja, merasa telah memiliki pengetahuan tentang mutu produk yang tinggi, yang diperoleh secara turun temurun, tetapi pekerja merasa pengetahuan tentang mutu produk rendah karena tidak ada perubahan tentang mutu produk selama bertahuntahun.

Mutu pada ceprek melinjo yang diproduksi ini sesuai dengan bahan yang tersedia dipasaran serta memperhatikan komentar, harapan dan juga selera dari konsumen. Misalnya dalam hal ini, awal mulanya rasa pada ceprek melinjo itu hanya satu rasa saja yaitu rasa gurih. Namun sekarang rasa ceprek melinjo bertambah yaitu rasa manis gula merah dan pedas. Itu merupakan saran yang disampaikan konsumen kepada BapakHD. Dalam menentukan bentuk dari ceprek melinjo ini, berdasarkan atas kebiasaan turun temurun. Dan bentuk khas dari ceprek melinjo Rumah Emping milik Bapak HD ini seperti bentuk lingkaran kecil. Dalam menentukan kemasan ceprek melinjo, pemilik dan pekerja usaha mikro ceprek melinjo Rumah Emping Sarijaya milik Bapak HD ini dengan menampilkan nama merek ceprek melinjo, yaitu Rumah Emping Sarijaya agar dikenal oleh masyarakat dan juga wisatan yang sedang berkunjung. Dalam memproduksi ceprek melinjo ini HD memproduksi ceprek melinjo yang seperti biasa ceprek melinjo yang diproduksi orangtua, namun ceprek melinjo Rumah Emping milik Bapak HD tersedia dalam 3 rasa: gurih, manis dan pedas. Ceprek melinjo ini pun tidak menggunakan bahan pengawet yang bersifat berbahaya. Ceprek melinjo ini termasuk makanan yang tahan lama, tahan hingga sampai 6 bulan.Pemilik dan pekerja usaha makanan ringan gipang telah memiliki kompetensi pengetahuan tentang daya saing produk yang tinggi dan dinyatakan dalam bentuk gipang yang berbentuk belah ketupat dan kemasan dalam toples plastik agar tidak mudah pecah untuk menarik perhatian konsumen. Berbeda dengan pemilik dan pekerja usaha mikro makanan ringan gipang, pemilik dan pekerja usaha makanan ringan ceprek melinjo menggunakan kemasan yang khas agar pelanggan mudah mengenali ceprek melinjo buatan Rumah Emping Sari Jaya ini dengan menggunakan plastik transaparan yang menempel nama produk dan nama toko pada depan kemasan. Hal tersebut sesuai yang dikemukan oleh Spencer dan Spencer (1993) bahwa kompetensi merupakan karakteristik mendasar seseorang, yang menentukan terhadap hasil kerja yang terbaik dan efektif sesuai dengan kriteria yang ditentukan dalam suatu pekerjaan atau situasi tertentu. Kompetensi menentukan perilaku dan kinerja (hasil kerja) seseorang dalam situasi dan peran yang beragam. Eggland (1989) mengatakan kompetensi sebagai kemampuan yang dimiliki seseorang, sehingga yang bersangkutan dapat menyelesaikan perannya. Dengan demikian, tingkat kompetensi seseorang dapat digunakan untuk memprediksi bahwa seseorang akan mampu menyelesaikan pekerjaannya dengan baik atau tidak. Hasil analisis menunjukkan bahwa pemilik dan pekerja usaha gipang dan ceprek sebagian besar sudah mampu menyelesaikan pekerjaan dengan baik dalam pengetahuan tentang mutu dan daya saing produk.

Keterampilan dalam pengolahan pangan sesuai standar mutu baik pemilik dan pekerja usaha gipang maupun ceprek melinjo ditentukan oleh pemilik usaha yaitu Ibu MHM (gipang) dan Bapak HD (ceprek melinjo). Ibu MHM selaku pemilik usaha gipang merasa bahwa pekerja usahanya telah memiliki keterampilan yang baik karena menggunakan tenaga keluarga yang ada, tenaga yang telah berpengalaman, serta terlatih dalam proses pembuatan gipang. Pemilik dan pekerja usaha mikro makanan ringan gipang ini dalam meningkatkan keterampilan dalam pengolahan gipang dilatih oleh Ibu MHM sendiri. Sedangkan pemilik dan pekerja usaha mikro makanan ringan ceprek melinjo tingkat keterampilan dalam pengolahan pangan sesuai standar mutu ini kebanyakan pekerja usaha mikro makanan ringan ceprek melinjo ini bahwa dalam proses pengolahan ceprek melinjo ini, ditentukan oleh tenaga yang terlatih dan berpengalaman, yang 
Tabel 3. Hubungan antara Profil Sosial Ekonomi Pemilik dan Pekerja Usaha terhadap Tingkat Kompetensi

\begin{tabular}{lcc}
\hline $\begin{array}{l}\text { Karakteristik Profil sosial Ekonomi Pemilik } \\
\text { dan Pekerja Usaha }\end{array}$ & $\mathbf{r}_{\mathrm{s}}$ & Sig. \\
\hline Umur & $-0,161$ & 0,231 \\
Motivasi Instrinsik & 0,245 & 0,067 \\
Motivasi Ekstrinsik & 0,191 & 0,154 \\
Pengalaman usaha & $-0,369^{* *}$ & 0,005 \\
Jumlah pendapatan (Rp) & $-0,371^{* *}$ & 0,004 \\
\hline
\end{tabular}

*Signifikan pada $\alpha=0,05$ (2-tailed).

$* *$ Signifikan pada $\alpha=0,01$ (2-tailed).

sebelumnya telah dilatih oleh pemilik usaha yaitu Bapak HD. Hal tersebut sesuai yang dikemukakan oleh Philip Crosby (1991) bahwa keterampilan dalam pengolahan pangan sesuai standar mutu, menurut mutu adalah sama dengan persyaratan-persyaratan. Mutu berarti memberikan produk, jasa atau informasi yang memenuhi persyaratan yang dimengerti bersama dengan pelanggan. Hasil analisis menunjukkan bahwa pemilik dan pekerja usaha gipang dan ceprek sebagian besar sudah memiliki keterampilan dalam kategori tinggi dan sedang.

Sikap pemilik dan pekerja usaha dalam meningkatkan mutu dan daya saing produk termasuk dalam kategori rendah sampai sedang. Hasil analisis menunjukkan bahwa pemilik dan pekerja usaha yang tua memiliki sikap dalam meningkatkan mutu produk dan daya saing seperti ditunjukkan oleh hasil kerja yang lebih baik, terutama pada pembuatan gipang dan ceprek melinjo. Mereka lebih banyak pengalaman yang didapat mengenai cara pengolahan makanan ringan gipang dan ceprek melinjo dan juga lebih dalam cepat menghasilkan produk makanan ringan dibandingkandenganumur yang masih muda. Pemilik dan pekerja usaha mikro makanan ringan gipang dan ceprek melinjo dalam meningkatkan mutu dan daya saing didasarkan pada saran yang diberikan oleh konsumen terhadap produk makanan ringan ini. Pemilik dan pekerja usaha, selalu berusaha untuk memperoleh saran dari konsumen dengan cara menanyakan kepada konsumen yang datang membeli produk makanan ringan gipang dan ceprek melinjo. Pemilik dan pekerja yang lebih tua lebih banyak memiliki pengalaman dalam proses pengolahan produk gipang dan ceprek melinjo. Akan tetapi pendapat menurut Padmowihardjo (1994) mengatakan bahwa seseorang yang semakin tua yaitu dengan umur di atas 50 tahun kemampuan yang di miliki akan berkurang hal ini di sebabkan oleh fungsi kerja otot dan otak yang semakin menurun dan semakin lambat dalam menerima adopsi inovasi, sehingga cenderung dalam melaksanakan kegiatan - kegiatan yang sudah biasa di lakukan. Hasil-hasil penelitian tersebut didukung oleh data kuantitatif seperti tercantum pada tabel 2.

\section{Faktor-Faktor yang Berhubungan dengan Kompetensi Penjaminan Mutu Gipang dan Ceprek Melinjo}

Hasil uji korelasi Spearman untuk mengetahui derajat hubungan antara faktor-faktor yang berhubungan dengan kompetensi memperlihatkan bahwa pengalaman usaha dan jumlah pendapatan yang berhubungan dengan kompetensi.

Pengalaman usaha memiliki hubungan dengan pengetahuan tentang mutu produk, pengetahuan tentang daya saing produk, keterampilan dalam pengolahan pangan sesuai standar mutu, sikap pemilik dan pekerja usaha dalam meningkatkan mutu dan daya saing. Hal ini karena pekerja usaha yang berpengalaman lama tidak sempat mempelajari pengetahuan tentang halhal tersebut diatas; pekerja usaha yang muda yang mempunyai kesempatan mempelajarinya, walaupun pekerja tidaksempat melakukannya karena masih fokus pada peningkatan keterampilan dasar dalam pembuatan makanan ringan gipang dan ceprek melinjo. Rakhmat (2001) menyatakan bahwa pengalaman berkaitan dengan kepemilikan pengetahuan. Pengalaman dan modal usaha dapat digunakan untuk mengembangkan usaha. Peningkatan pengetahuan dan keterampilan juga diperoleh melalui pelatihan.

Jumlah pendapatan cenderung berkaitan dengan pengetahuan tentang mutu produk, pengetahuan tentang daya saing produk, keterampilan dalam pengolahan pangan sesuai standar mutu, sikap pemilikdan pekerja 
Tabel 4. Hubungan antara Dukungan Eksternal Pemilik dan Pekerja terhadap Tingkat Kompetensi

\begin{tabular}{|c|c|c|}
\hline $\begin{array}{l}\text { Karakteristik Dukungan Eksternal } \\
\text { Pemilik dan Pekerja Usaha }\end{array}$ & $\mathbf{r}_{\mathrm{s}}$ & Sig. \\
\hline Tingkat pemanfaatan informasi & $0,371^{* *}$ & 0,004 \\
\hline Tingkat pengawasan mutu produk & $0,649^{* *}$ & 0,000 \\
\hline Kemitraan & $-0,289^{*}$ & 0,029 \\
\hline
\end{tabular}

**Signifikan pada $\alpha=0,01$ (2-tailed).

*Signifikan pada $\alpha=0,05$ (2-tailed)

usaha dalam meningkatkan mutu dan daya saing. Berdasarkan pengamatan di lapangan dan hasil wawancara diketahui bahwa sebagian besar pemilik dan pemilik dan pekerja usaha bahwa peningkatan mutu dan daya saing produk yang didasari oleh peningkatan pengetahuan dan keterampilan akan menghasilkan produk yang lebih baik, tetapi dengan harga yang lebih tinggi sehingga pendapatan dapat meningkat. Pemilik dan pemilik dan pekerja usahajuga khawatir bahwa dengan harga yang lebih tinggi, mereka akan kehilangan konsumen yang telah ada.

Umur tidak memiliki keterkaitan dengan pengetahuan tentang mutu produk, pengetahuan tentang daya saing produk, keterampilan dalam pengolahan pangan sesuai standar mutu dan sikap pemilik dan pekerja usaha dalam meningkatkan mutu dan daya saing. Hal ini karena hal-hal tersebut merupakan keterampilan yang dipelajari sambil mengerjakannya, dan umur pekerja usaha tidak jauh berbeda. Hal ini dapat dilihat bahwa usia ini tergolong usia produktif seseorang dalam bekerja, sehingga mereka lebih memilih bekerja sebagai berwirausaha dengan harapan akan mendapatkan kinerja yang produktif, dan memperoleh keberhasilan dalam hidupnya. Hasil penelitian ini sejalan dengan penelitian Subaedi (2010) bahwa umur tidak berhubungan dengan kompetensi.

Motivasi, baik motivasi instrinsik maupun motivasi ekstrinsik, tidak menunjukkan keterkaitan dengan kompetensi pemililk dan pekerja usaha. Kemungkinan besar motivasi pemilik dan pekerja usaha mikro gipang maupun ceprek melinjo baru sampai pada menghasilkan produk sebaik dan sebanyak mungkin, belum ada motivasi kearah pengembangan usahanya terutama dalam meningkatkan mutu dan daya saingnya.Weiner (1990) mengemukakan bahwa motivasi sebagai kondisi internal yang membangkitkan orang untuk bertindak, mendorong orang mencapai tujuan tertentu, dan membuat orang tetap tertarik dalam kegiatan tertentu.
Sumber modal tidak memiliki keterkaitan dengan pengetahuan tentang mutu produk, pengetahuan tentang daya saing produk, keterampilan dalam pengolahan pangan sesuai standar mutu, sikap pemilik dan pekerja usaha dalam meningkatkan mutu dan daya saing. Sumber modal pemilik usaha gipang dengan menggunakan modal sendiri, dan intensitas usaha didasarkan pada modal yang tersedia. Sedangkan untuk sumber modal pemilik usaha ceprek melinjo dengan menggunakan sumber modal pinjaman dana bank swasta. Sumber modal hanya dipergunakan untuk memperoleh modal usaha, dan tidak terkait dengan pengetahuan aspek-aspek kompetensi. Menurut Bambang Riyanto (2004), bahwa sumber dana yang dapat diperoleh untuk membelanjai suatu perusahaan adalah: Sumber dana dari dalam perusahaan (internal source) dapat diartikan sebagai bentuk dana dimana pemenuhan kebutuhan dananya berasal dari dalam perusahaan itu sendiri, dengan kata lain dana dengan kekuatan atau kemampuan sendiri dan sumber dana dari luar perusahaan (external source) yaitu pemenuhan kebutuhan dana diambil atau berasal dari sumbersumber dana yang ada di luar perusahaan. Dana yang berasal dari luar perusahaan adalah dana yang berasal dari pihak bank. Hasil-hasil penelitian tersebut didukung oleh data kuantitatif seperti tercantum pada tabel 3 .

\section{Keterkaitan Dukungan Eksternal terhadap Tingkat Kompetensi Pemilik dan Pekerja Usaha Gipang dan Ceprek Melinjo}

Tingkat pemanfaatan informasi, yang diberikan oleh pemilik usaha meningkatkan kompetensi pekerja usaha untuk meningkatkan kompetensi mereka menjadi lebih baik. Dengan demikian maka tingkat pemanfaatan informasi terkait dengan tingkat kompetensi pemilik dan pekerja usaha dalam hubungan positif.

Tingkat pengawasan mutu akan mempengaruhi 
Tabel 5. Matrik SWOT Usaha Gipang dan Ceprek Melinjo

\begin{tabular}{|c|c|c|}
\hline Faktor Internal & $\begin{array}{ll}\text { KEKUATAN } \\
\text { 1. } & \text { SDM yang melimpah } \\
\text { 2. } & \text { Harga bersaing } \\
\text { 3. } & \text { Lokasi dekat dengan pemasok } \\
& \text { bahan baku } \\
\text { 4. } & \text { Pantang menyerah }\end{array}$ & $\begin{array}{ll}\text { KELEMAHAN } \\
\text { 1. } & \text { Kurangnya pengawasan proses } \\
\text { produksi dan kualitas } \\
\text { 2. } \\
\text { Pencatatan keuangan masih } \\
\text { sederhana } \\
\text { 3. } \text { Terbatasnya akses pasar }\end{array}$ \\
\hline $\begin{array}{ll}\text { PELUANG } \\
\text { 1. } & \text { Produk telah dikenal } \\
\text { masyarakat } \\
\text { 2. } \text { Memiliki sistem } \\
\text { pemasaran terpusat } \\
\text { 3. } \text { Banyaknya mitra } \\
\text { 4. Terbukanya toko online } \\
\text { 5. Perkembangan ekonomi } \\
\text { kreatif }\end{array}$ & 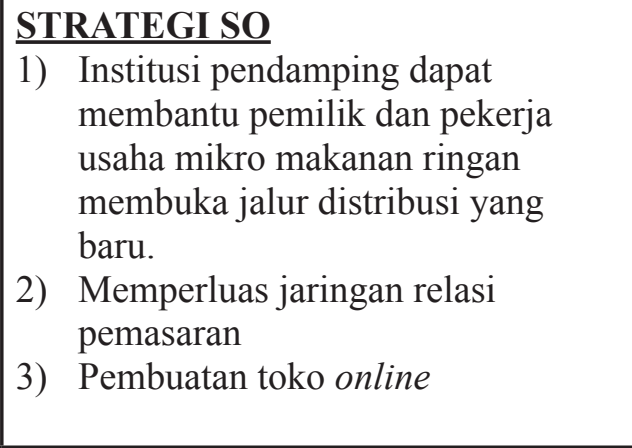 & $\begin{array}{l}\text { STRATEGI WO } \\
\text { 1) Institusi pendamping dapat menjadi } \\
\text { fasilitator Pelatihan kewirausahaan, } \\
\text { manajemen persediaan, branding dan } \\
\text { desain produk. } \\
\text { 2) Mengalokasikan dana membuat } \\
\text { katalog dan sampel produk baru. } \\
\text { 3) Institusi pendamping dapat } \\
\text { memfasilitasi untuk pengembangan } \\
\text { produk baru. }\end{array}$ \\
\hline $\begin{array}{ll}\text { ANCAMAN } \\
\text { 1. } & \text { Kekuatan daya tawar } \\
\text { pemasok bahan } \\
\text { 2. } \\
\text { Pesaing : dari dalam } \\
\text { negeri dan dari luar } \\
\text { negeri }\end{array}$ & $\begin{array}{ll}\text { STRATEGI ST } \\
\text { 1) } & \begin{array}{l}\text { Institusi pendamping dapat } \\
\text { mendorong Pemerintah untuk }\end{array} \\
& \text { membatasi impor makanan ringan } \\
& \text { khas Banten. } \\
\text { 2) } & \begin{array}{l}\text { Mengoptimalkan kerjasama } \\
\text { pemilik dan pekerja usaha mikro }\end{array} \\
& \text { makanan ringan dengan anggota } \\
& \text { koperasi agar mampu menyediakan } \\
& \text { bahan baku. } \\
\text { 3) } & \text { Institusi pendamping dapat } \\
& \text { memfasilitasi promosi bersama } \\
& \text { dengan mengadakan pameran. }\end{array}$ & $\begin{array}{l}\text { STRATEGI WT } \\
\text { 1) } \begin{array}{l}\text { Membangun kekuatan bersama } \\
\text { melalui koperasi dan komunitas }\end{array} \\
\text { UKM. } \\
\text { 2) Institusi pendamping dapat } \\
\text { memfasiltasi untuk Pemerintah } \\
\text { membuat regulasi dan kebijakan } \\
\text { yang mendukung pengembangan } \\
\text { usaha UKM. }\end{array}$ \\
\hline
\end{tabular}

hasil kerja pemilik dan pekerja usaha makanan ringan gipang dan ceprek melinjo karena dengan pengawasan ini mereka berusaha untuk bekerja sebaik mungkin, dengan memanfaatkan kompetensi yang mereka miliki. Dengan demikian tingkat pengawasan mutu terkait dengan tingkat kompetensi pemilik dan pekerja usaha gipang dan ceprek melinjo dalam hubungan positif. Menurut Agri-Food Business Development Centre (2007), pada pasar global diperlukan standar yang menggambarkan karakteristik mutu pangan dan prosesnya karena adanya sifat saling membutuhkan antara produsen dan konsumen. Mutu pangan dapat dihubungkan dengan beberapa hal, yaitu: kualitas sensori yang meliputi bentuk, rasa, tekstur, dan warna; cara mempertahankan produk; keamanan produk dan kemasan produk.

Kemitraan terkait dengan kompetensi pemilik dan pekerja usaha gipang dan ceprek melinjo. Mitra usaha tentu mengharapkan hasil usaha gipang dan ceprek melinjo yang terbaik. Walaupun demikian, pemilik usaha gipang belum memanfaatkan kemitraan karena merasa lebih baik mengandalkan kemampuan keluarganya; sedangkan untuk bermitra dengan pihak lain, dirasakan harus melalui prosedur yang rumit dan sulit. Karena itu pemilik usaha mempergunakan kompetensi yang mereka miliki sebaik mungkin untuk memenuhi harapan mitra usaha tersebut. Berdasarkan pendapat Spencer (1977) kemitraan adalah suatu persekutuan dari dua orang atau lebih sebagai pemilik bersama yang menjalankan suatu bisnis mencari keuntungan. Pandangan ini mengindikasikan bahwa pemilik dan pekerja apabila menjalin kemitraan akan lebih mudah untuk meningkatkan kemajuan usaha.

Berdasarkan hasil analisis penelitian pemilik dan pekerja usaha yang telah mengikuti pelatihan lebih banyak menunjukkan tingkat kompetensi yang lebih baik. Hal ini terlihat dari mutu dan jumlah produk yang dihasilkan oleh pemilik dan pekereja usaha. Pemilik 
dan pekerja usaha usaha mikro makanan ringan gipang dan ceprek melinjo telah banyak mengikuti pelatihan, memiliki pengetahuan keterampilan dan sikapnya yang lebih baik dan meningkatkan kompetensi pemilik dan pekerja usaha mikro makanan ringan itu tersebut. Demikian pula kompetensi yang meningkat ini tentunya karena metode pelatihan yang baik.Berdasarkan hasil pengamatan dilapangan dan wawancara bahwapemilik dan pemilik dan pekerja usaha usaha mikro makanan ringan gipang dan ceprek melinjo telah banyak mengikuti pelatihan dengan berbagai macam cara metode pelatihan pengetahuan keterampilan dan sikapnya akan meningkatkan kompetensi pemilik dan pekerja usaha mikro makanan ringan itu tersebut. Hasil-hasil penelitian tersebut didukung oleh data kuantitatif seperti tercantum pada Tabel 4.

\section{Strategi Pengembangan dalam Meningkatkan Kompetensi Pemilik dan Pekerja Usaha Pengolahan Pangan Makanan Ringan}

Berdasarkan analisis SWOT dengan membandingkan faktor peluang dan kekuatan (Strategi SO), peluang dan kelemahan (Strategi WO), kekuatan dan ancaman (Strategi ST), serta kelemahan dan ancaman (Strategi WT), maka dapat dimunculkan beberapa strategi dalam pengembangan usaha yang bisa dilakukan oleh pemilik dan pekerja usaha mikro makanan ringan dan institusi pendamping (Pemerintah, BUMN, Perusahaan Swasta, dan Perguruan Tinggi):

Strategi Pengembangan yang bisa dilakukan pemilik dan pekerja usaha mikro makanan ringan:

1. Memperluas jaringan relasi kerjasama atau kemitraan.

2. Membuat toko online dan pendaftaran link diberbagai portal bisnis online

3. Mengalokasikan dana membuat katalog dan sampel produk baru.

4. Mengoptimalkan kerjasama pemilik dan pekerja usaha mikro makanan ringan dengan koperasi agar mampu menyediakan bahan baku dengan harga terjangkau.

5. Membangun kekuatan bersama melalui koperasi dan komunitas UKM.

Strategi Pengembangan yang bisa dilakukan Institusi Pendamping:

1. Membantu pemilik dan pekerja usaha mikro makanan ringan dalam membuka jalur distribusi yang baru.

2. Memfasilitasi promosi bersama dengan mengadakan pameran.

3. Institusi pendamping dapat membantu pemilik dan pekerja usaha mikro makanan ringan membuka jalur distribusi yang baru.

4. Menyelenggarakan pelatihan berkala dan berkesinambungan tentang: kewirausahaan, manajemen persediaan, branding dan desain produk.

5. Memfasilitasi pengembangan produk baru.

\section{Kesimpulan}

Tingkat kompetensi dalam pengolahan makanan ringan pemilik dan pekerja usaha mikro gipang termasuk tinggi, sedangkan kompetensi pemilik dan pekerja usaha mikro makanan ringan ceprek melinjo termasuk dalam kategori rendah. Tingkat kompetensi pemilik dan pekerja usaha gipang diperoleh secara turun temurun dengan fasilitasi oleh pemilik usaha, sedangkan kompetensi pemilik dan pekerja usaha ceprek melinjo diperoleh dari pelatihan usaha dan keluarganya, yang sebelumnya telah memperoleh secara turun temurun.

Strategi Pengembangan yang bisa dilakukan pemilik dan pekerja usaha mikro makanan ringan dengan cara memperluas jaringan relasi pemasaran, membuat toko online dan pendaftaran link diberbagai portal bisnis online, mengalokasikan dana membuat katalog dan sampel produk baru, mengoptimalkan kerjasama pemilik dan pekerja usaha mikro makanan ringan dengan koperasi agar mampu menyediakan bahan baku dengan harga terjangkau dan membangun kekuatan bersama melalui koperasi dan komunitas UKM.

\section{Daftar Pustaka}

Bungin MB. 2007. Penelitian Kualitatif: Komunikasi, Ekonomi, Kebijakan Publik, dan Ilmu Sosial Lainnya. Jakarta (ID): Kencana Prenada Media Group.

Camagni R. 2002. On the concept of territorial competitiveness Sound or Misleading? ERSA Conference papers European Regional Science Association.

Catano VM. 1998. Competencies: A Review of the 
Literature and Bibiliography.

Creswell JW. 2002. Research Design: Qualitative and Quantitative Approaches. London: Sage Publications.

Danger EP. 1992. Selecting colour for packaging. England: Gower Technical Press Ltd.

Irawan. 2010. Variasi, Pemanfaatan, Pengolahan dan

Pengelolaan Aren di Desa Rancakalong, Kecamatan

Rancakalong, Kabupaten Sumedang, Jawa Barat. Jurusan Biologi Fakultas Matematika dan Ilmu Pengetahuan Alam, Universitas Pandjajaran.

Marlianti. 2008. Faktor-faktor Penentu Peningkatan Kinerja Penyuluh Pertanian Dalam Memberdayakan Petani (Kasus di Kabupaten Kampar Provinsi Riau) [Tesis]. Bogor (ID): Program Pascasarjana, Institut Pertanian Bogor.

Marzuki MS. 1992. Strategi dan Model Pelatihan, Malang (ID): IKIP Malang.

Moleong LJ. 2007. Metodologi Penelitian Kualitatif. Bandung (ID): Remaja Rosda Karya.

Mulyasa. 2002. Kurikulum Berbasis Kompetensi.

Konsep, Karakteristik, dan Implementasi. Bandung (ID): Remaja Rosdakarya.

Rakhmat D. 2001. Metode Penelitian Komunikasi. Bandung (ID): PT. Remaja Rosdakarya.

Rangkuti F. 2006. Analisis SWOT Teknik Membedah Kasus Bisnis. Jakarta (ID): PT. Gramedia Pustaka Utama.

Riyanto B. 2008. Dasar-dasar Pembelanjaan Perusahaan. Yogyakarta (ID): Penerbit GPFE.

Siegel S. 1994. Statistik Non Parametrik. Jakarta (ID):
Pustaka Utama.

Spencer LM, Signe M. 1993. Competence Work: Model for Superior Performance. John Wiley and Sons, Inc Sriyana J. 2009. Strategi Pengembangan Usaha Kecil dan Menengah (UKM): studi kasus di Kabupaten Bantul Provinsi DIY. Yogyakarta (ID): Universitas Islam Indonesia.

Subaedi. 2010. Kompetensi SDM UKM dan Pengaruhnya Terhadap Kinerja UKM di Surabaya. Jurnal Manajemen Dan Kewirausahaan, 12(1): 42-55.

Suryabrata S. 2003. Metodologi Penelitian. Yogyakarta (ID): Raja Gravindo Persada.

Sugiyono, 2008. Metode Penelitian kuantitatif, Kualitatif, dan R \& D. Bandung(ID): ALFABETA. Soeprihanto J. 1996. Penilaian Kinerja dan Pengembangan Karyawan. Edisi Pertama. Cetakan Kedua. Yogyakarta.

Susilo. 2008. Kinerja Industri Kecil di Kabupaten Bantul Provinsi DIY. Simposium Nasional 2010: Menuju Purworejo Dinamis dan Kreatif.

Susilo Y, Krisnadewara PD. 2007. "Strategi Bertahan Industri kecil Pasca Gempa Bumi di Yogyakarta", Ekonomi dan Bisnis, IX (2), Juni 2007.

Sutopo HB. 2006, Metode Penelitian Kualitatif, Surakarta (ID): UNS Press.

Tarigan. 2008. Kinerja Industri Kecil pada Industri Kerajinan Perak di Kota Yogyakarta. Simposium Nasional 2010: Menuju Purworejo Dinamis dan Kreatif. 